\title{
Preserving the American Heritage in a Regimented Society'
}

Dr. Orne is director, Air University Library, Maxwell Air Force Base, Alabama.

$\mathrm{T}$

HE FREEDOM TO THINK, to compare, and to choose is the birthright of every American. Preserving this American heritage of free thinking in a powerful and regimented organization such as the U.S. Air Force is a problem few nations would be willing or able to face directly. Only a country as dedicated to freedom as America can nourish patriotism and not revolt by allowing, indeed requiring, such freedom of choice.

Let us first establish what we mean by a regimented society. On the face of it, it would seem that we are talking at cross purposes when we speak of freedoms on the one hand, and regimentation on the other. Yet, all of our most valued freedoms, those incorporated in the first amendment to the Constitution, are established by law; the law is a form of regimentation. It seems that we are legally required to be free.

To be more serious, however, the regimented society I want to talk about is one whose future is now partly my own responsibility- the U.S. Air Force. No one can deny that the U.S. Air Force is a regimented society. Any military organization has an absolute requirement for regimentation. The disciplined mind, the disciplined body, freedom from indecision, all are highly prized qualities in the military man. Historically, the final success of any military

1 Address given at the 48 th annual convention of the Alabama Library Association, Birmingham, Ala., April 25, 1952. machine is directly proportionate to the level of military discipline and the extent of regimentation throughout the ranks.

The Air Force, as we know it today, is a relatively new organization. Only recently did it receive its autonomy; with this autonomy, it faced a tremendous task. To a world shrunken by air travel, air power had become the United States' greatest defense from aggression. Molding the new facets of air power into a machine which by necessity operates like no other organization of war, demanded leaders with imagination, foresight, and originality.

Remember that the U.S. Air Force had to start with a core of long-time U.S. Army officers, Army flying officers. Thus, the basic element of standard organization, of a regimented society, were passed on to the fledgling branch of the services. These men, the old-time Army men, from private to general, had been indoctrinated over years, and in some cases decades, of devoted service to the traditional ideals of service according to an established pattern.

To meet the unprecedented challenge of a new organization, this Air University was conceived; a university that would develop leaders from their own ranks of the Air Force; a university which now can claim to be the largest university in the world, with over 160,000 students. There was no existing pattern for this kind of school. Just as the Air Force itself had to strike out along modern progressive paths, the Air University had to chart a new course in education. 
The standards of this new school were defined in the words of the late General Fairchild, who was the first Commanding General of the Air University, in an address to the first class.

He said, "One of the basic policies which we have adopted is the avoidance of traditionalism, rigidity of thought and doctrine, standardization of instruction, and the provision of dogmatic answers to the problems of the future.

"We must guard rigorously against the danger of looking backward too much, against the feeling that we have learned the answers to future war. We must be on guard against building up resistance to change, against taking the easy course of accepting answers from the past instead of the infinitely more difficult course of digging them out of the future... This is not a post-war school system-it is a pre-war school system!"

For the benefit of those who do not know very much about the Air University, I would like to say just a little bit about what it is and then I will go on to make the point of its relationship to the American heritage.

Under the Air University are a unique group of schools, with courses as diverse as the Air Force itself. The Air War College is the top level school of the Air Force. It is one of the schools within the Air University. It is devoted to the education of selected officers of high level for high command and staff duties. They are trained in diplomatic and international relations as well as military matters. With wellordered, resourceful and original thought a foremost objective, this school advocates no "school solution."

The most extensive program of residence instruction is conducted in the Air University's second school-the Air Command and Staff School, which has seven specialized staff courses in addition to the general courses for commanders. Here, again, the
Air University continues its search for leaders of the future.

The Air Force School of Aviation Medicine, with headquarters located at Randolph Air Force Base in Texas, and in part at Gunter Air Force Base in Montgomery, has the task of instructing flight surgeons, flight nurses, and flying medical technicians. Instruction is only a part of this school's mission. To keep pace with aviation, it conducts research towards the prevention and cure of ailments brought about by air travel.

Another school of the Air University system is the Air Force Institute of Technology, center of advanced technical and scientific education in the Air Force. This school, located at Wright-Patterson Air Force Base in Dayton, Ohio, educates officers in engineering sciences and industrial administration in addition to conducting a training-in-industry program involving the cooperation of more than sixty industries.

The Extension Course Institute, another part of the Air University, provides education by mail to approximately 40,000 students, and the centralization of Air ROTC at Maxwell will bring over I00,000 new students into the working area of the Air University. 'This, then, is the system which the Air University Library must supporta challenge not easily met.

Now, to get back to this heritage we have heard so much about and which seems to mean different things to different people. To me, the core of the American heritage is the freedom to think, compare, and to choose; whether this be accomplished by reading, by discussion, or by simple reflection is another matter. The means is of little importance, so long as this freedom is maintained.

In the regimented society described above, no doubt many of you will wonder how this freedom can live. I would not have you believe for a minute that we are heroic li- 
brarians at the Air University, engaged in hand-to-hand combat with a regimented society determined to kill off our freedom. On the contrary, it is because the facts are all to the contrary that this story deserves to be told.

The Air Force, at least insofar as it is represented at the Air University, is committed to the concept of promoting untrammeled, unregimented thought in its officers and men. Let me give you some of the evidence of this:

The Air University Library, working with a military library committee, which is internal, and a civilian Library Advisory Board, which is external, has recently completed a written statement of acquisitions policy which states the acquisitions program for the Air University Library for the foreseeable future. This policy is both broad and deep. There are exclusions made to better coordinate our program with other branches of the Air University, such as the School of Aviation Medicine and the U.S. Air Force Institute of 'Technology, and for better coordination of our program with nearby and related civilian institutions. But there are no exclusions for reasons of prejudice or opinion.

Note that this policy has been formulated by both military and civilian and the most lasting impression $\mathrm{I}$ have from my work with this policy is that everyone was completely concerned with what we should have and no one nearly as much concerned with what we should not have. Note also the presence of a civilian board of review, whose advice, I can assure you, is valued and used. First point, then, freedom of selection.

Now it is not enough to have all of the books if they are not seen or used. This point has been made and will be made again and again. Even a library having all kinds of materials can be twisted into ineffectiveness by labeling, by segregation, or by isolation.
The Air University not only does not tolerate segregation, labeling, or isolation; it teaches the opposites. The officers and men at our schools are expected to consider every aspect of a problem before reaching a decision. The methods of instruction at the Air University greatly resemble the program now moving under the American Library Association American Heritage project. Group discussion is a basic part of most courses. A unit of study is commonly initiated with a lecture; then the class is broken into small units of six to nine men and the problem is discussed in seminar. There is not a "school decision" which they are expected to reach. There is a leader, but his part in the decision is only as much as that of any other one member of the group. In fact his decision may not be the final one. After sufficient group discussion they formulate a group decision and one member of the group is selected to present their decision orally to the entire class. The decision they have reached may be attacked by any of the whole group and frequently is. Out of nine different groups may come nine different decisions, not one of them being wholly tenable or conforming to Air Force policy. This is not important; what is important is that they are free to talk, to discuss, to advocate, every or any aspect of a problem, and to back up their words with thinking. They are expected to read on all sides of the question, to weigh every angle in the balance of objective intelligence, and to learn how to fit the results of their study into good problem solving. All of the primary elements of the American Library Association's American Heritage project are the same points designated by the Air University as the major means of educating Air Officers for the future. They must be willing to listen; group discussion makes this imperative. They must be free of prejudice; the school gives them no "school de- 
cision," and will say in effect, "There is no right answer, what is yours?"

Problem solving, effective communication, group discussion are the fundamental aspects of the American Heritage program in common with the program of the Air University. Without laboring this point any longer, it is plain that despite the seemingly regimented exterior, within beats a heart of gold, our valued American heritage.

Labeling, segregation, isolation, have no place in our library; indeed the library would work against the planning of the University if it were to practice any such selection. I did not know whether this could be true and I have tried to verify it before telling you it is so. Here is what I did. The list of books cited by Oliver Carlson in his review of Helen Haines' second edition was checked in our library, the list of books which he cited as indicating her pro-Soviet leaning. Every single title of the list was in our library.

I was shown an article in the American Legion Magazine which I talked about recently. This article had to do with what reviewers could do to books and book production. The article discusses a list of anywhere from a dozen to twenty books on each side of the Soviet question, pro and con. This list was checked and every book but one was in our library, on both sides of the question.

To come at censorship from another point of view, one might expect that the book by Marshall Andrews which is called Disaster Through Air Power would not be in our library. It is absolutely contrary to anything that the Air Force believes. It is not only in the library, but it is required reading for some courses at the Air University. Obviously, it is the intent of Air University policy to give its future leaders complete freedom of thought and action.

My next points have to do with a part of what I consider freedom of inquiry, not related to books, and this is one of the main reasons why I thought it would be such a fine thing to come to the Air University to work. It is that libraries in many places are hampered in their work by traditions other than those related to books : traditions of methods of work, how you do your job, the kinds of people you use to do your jobs, and things of this kind. We have a freedom at the Air University which I find most enjoyable, and that is freedom of methodological attack upon the problems of the library. We come by this freedom perhaps a little unfairly because the men of the Air Force are not librarians. They are the first to confess that they know very little about libraries. They are humble enough to say they don't know and to let somebody come along and say, "I think I know how to do it" and try it. This is a freedom which I value very greatly and a freedom which many librarians can not get. We have this freedom and because of it we are able to do some experimentation which may yield long-lasting results and have an important effect, and which are in effect, our part of our American heritage: the freedom of inquiry, whatever the field.

I have listed a number of ways in which we are trying this out. Mention has been made frequently of how difficult it is to reach the user. No matter how much you have in your library, if you don't reach the user, it will do you little good. We are initiating an experiment at the Air University Library under which we are going out to get the user. We have librarians on our staff now, and we will have more, who are free to move in or outside of the Library. They are scheduled for a minimum of time at a desk and they are intended to be "salesmen" for the Library. We call them Bibliographic Assistants. They are assigned to a course of instruction. Usually the courses 
will have anywhere from 60 to 500 men. Each Bibliographic Assistant will concentrate on his or her particular course of instruction. They may go to classes whenever they like, they consult with the instructors whenever they like. They are expected to be outside the Library working with their public as much as two-thirds of their time. This, roughly, is the amount of time that students are in classes in the course to which they are assigned. The other third is more or less euphemistically called "free time" when the students are free to study and we expect our Bibliographic Assistants to be back in the Library where they will meet their particular public when they come in. This is a kind of freedom of action that librarians seldom attain, and this is one way that I think ours is a contribution.

We have yet another kind of freedom of method within our regimented society. The men of the Air Force freely admit that they do not know very much about how you get at the materials in a book or a document. At the same time they have a completely open-minded attitude towards our methods of accomplishing this. We are going to be able to experiment even in cataloging. We are not hide-bound to maintain a catalog in its primitive form because it started that way, and grew that way for the last five, ten, fifteen, or forty years. If we, the librarians, were agreed that it should be done, I believe we could dispose of the catalog entirely. How many librarians have this much freedom of thought? We are not going to be as extreme as that, but we are going to try some new things. In most libraries, selective analysis of a series is not common. The more usual practice is a traditional one. You never know when one item will be asked for; you analyze the whole series. I think we will go a great deal further into selective analysis-we are forced into it. How would you like to be faced with 400,000 documents, of which perhaps only 40,000 have valuable material in them or which may be called for only once in ten years? Would you do complete analysis of series or would you do selective analysis? Understand this, 400,000 is only the beginning. There are many documents we are not getting. We could get a million, two million, and in time no doubt we will. We can experiment in this field; in fact there is an experiment in our Library already. I am not sure it is the best solution, but it is in use. This is the divided catalog. We have asked outside experts to look at it and we have talked about it. We study it and we have group discussion. In our group discussion we have not only library people but the people who use the catalog, and we will find out if it is the best if we can. And if it is not, we will break it up-we will change it. We have complete freedom of inquiry in methodology. To me this freedom is a very important part of our American heritage.

One more freedom I would like to speak of and then I will close. I have mentioned briefly a Library Advisory Board. Here again it seems to me the Air Force is out in front in exposing any of its operations to outside investigation or examination by people who may know better. I can assure you we regard very highly and give serious consideration to the advice we get. This Library Advisory Board of the Air University Library is a group of half a dozen or more outstanding librarians and educators who come in once or twice a year to review progress at the Air University Library and to advise the Commanding General concerning past, present and future operations of the Library. The Library, however, is only a small element of the Air University. The University, as a whole, has a civilian advisory board of the same kind. It is composed of the leading educators of the country, including the president of the Massachusetts Institute of Technology, who is the present chairman. There is one military 
man out of seven on that board. General Doolittle has only recently been added because the Air Force felt that the civilians might want a military advisor too. Now this, in my opinion, is a demonstration of the freedom of inquiry.

Now how does all this fit in making the American heritage and continuing the American heritage? Obviously, the Air Force has recognized and believes that it is going to be a leading example of the American heritage outside of this country. If it is going to be a good example it must live it, breathe it, and be it. They believe it is necessary to make Air officers different from what was considered the traditional type of officer, one who knew only Army regulations and lived by them, one who knew only discipline and used no imagination. The Air University is devoted to cultivating inquiry, encouraging freedom of action, promoting the use of imaginative intelligence in its officers. They believe that practicing all of these freedoms is the only way to indoctrinate, to inculcate this way of thinking in the Air officer. I believe that the illustrations I have given you may convince you, as they have me, that this is well worth doing; that it is a way of continuing the American heritage and of building toward it in every place where Air Force officers and people may go.

\section{Comparison of Group I Statistics, 1947-48-195 I-52}

Mr. Dale Bentz of the University of Tennessee Library, who compiled the Group I college and university library statistics printed elsewhere in this issue, presents the following interesting median comparisons :

Staff Salaries*

Books, Periodicals, and Binding

Total Library Operat-

ing Expenditures (Salaries)

Librarian

Dept. Head Minimum Maximum

Professional) Minimum Assistant $\int$ Maximum

I95I-52

\$ 49,9 I 9

93,037

272,629

265,494

236,603

242,776 216,508

$$
\text { - }
$$

* Excludes student service.

The above information is distorted by number and kind of libraries reporting, lack of continuity in reporting by institutions, etc. The table shows a steady increase in all categories (except three in $1949-50$ ).

\section{Commercial Standard for Library Binding}

Efforts are being made at present to have the U.S. Department of Commerce set up a "Commercial Standard" for library binding and rebinding. Since there is an established procedure in the Commerce Department to give everyone interested in a type of activity for which a commercial standard is proposed an opportunity to express his views, it would seem desirable that librarians and persons in charge of binding divisions be informed about this procedure and express their views on it. Any person who wishes to be kept informed as to the successive actions taken on this petition may address a request to $\mathrm{H}$. B. McCoy, Director, Officer of Industry and Commerce, U. S. Department of Commerce, Washington, D.C. 